\title{
FARM-MADE FEED FOR POLYUNSATURATED FATTY ACIDS (PUFAs) RICH CARP PRODUCTION IN INDIA: A CASE STUDY
}

\author{
B.N. Paul ${ }^{1}$, S.S. Giri ${ }^{2}$, S. Chanda ${ }^{1}$, S.C. Rath $^{2}$ and A.K. Datta ${ }^{1}$ \\ ${ }^{1}$ Regional Research Center, ICAR-Central Institute of Freshwater Aquaculture, Rahara, Kolkata- \\ 700118, West Bengal, India \\ ${ }^{2}$ ICAR-Central Institute of Freshwater Aquaculture, Kausalyaganga, Bhubaneswar-751002 \\ Odisha, India
}

\begin{abstract}
An 8 months feed demonstration program was conducted in the ponds of Ramakrishna Mission, Belur Math, West Bengal, India. The program aimed at providing hands-on training to trainees at Samaj Sevak Sikshan Mandir (SSSM) on farm-made feed formulation and use in aquaculture. Two ponds were selected, one at Shilpamandira of $0.1 \mathrm{~h}$ and fish were fed Feed-1, and another of $0.08 \mathrm{~h}$ at Samaj Sevak Sikshan Mandir (SSSM) and fed Feed-2. Indian major carps, Catla catla (catla) and Labeo rohita (rohu) were stocked at 4500 fish ha ${ }^{-1}$. The stocking size of rohu was $80-90 \mathrm{~g}$ and of catla was $220-245 \mathrm{~g}$. Locally available low cost feed ingredients, rice bran, mustard oil cake, til oil cake and linseed oil sludge were used to formulate and prepare two farm-made mash feeds (Feed-1 and Feed-2). The fish were fed at $2 \%$ of total fish biomass in the ponds and were fed through bag feeding. At the end of the study rohu grew to $1.07 \mathrm{~kg}$ and catla to $1.6 \mathrm{~kg}$ in Shilpamandira pond (Feed-1), and rohu to $1.5 \mathrm{~kg}$ and catla to $2.2 \mathrm{~kg}$ in Samaj Sevak Sikshan Mandir pond (Feed-2). The net production of fish was 4.9 and $6.8 \mathrm{t} \mathrm{ha}^{-1}$ for 8 months with Feed-1 and Feed-2, respectively. Dietary inclusion of linseed-oilsludge significantly increased the PUFA content in Indian major carps. The feed cost was substantially reduced by replacing mustard oil cake with til oil cake and incorporation of linseed oil sludge, a very low priced ingredient.
\end{abstract}

Keywords: Omega-3 fatty acids, carp poly culture, linseed oil, unconventional feed

\section{INTRODUCTION}

The fisheries sector occupies an important place in the socio-economic development of the country, which envisages livelihood, nutritional security, employment

\footnotetext{
* Corresponding author e-mail: bnpaulcifa@gmail.com
} 
generation and export earnings. Indian fisheries occupy the second position in global fish production and second in aquaculture in the world with an annual growth rate of $4.7 \%$, recording $3.2 \%$ growth in marine sector and $6.2 \%$ in inland sector (Paul and Giri, 2015). The fisheries sector has grown from traditional activity in the early fifties, when India initiated the first five year plan (1950-51 to 1955-56), and now transformed into significant commercial enterprise with impressive growth in production from 0.75 million tons in the 1950 s to 10.4 million tons (MT) during 2015-16. The sector has emerged as the largest single employer in the country for more than 14.5million people (DAHAD, 2015-16). About 35\% of the Indian population is fish eaters and the per capita consumption is $9.8 \mathrm{~kg}$, whereas present global per capita fish intake is over $20 \mathrm{~kg}$ (FAO, 2016) (http://www.fao.org/ news/story/en/item/icode/). Inland fisheries have emerged as a major contributor to the overall fish production in the country with a present share of $64.07 \%$ in total fish production. Within inland fisheries there is great shift from captured fisheries to aquaculture and at present freshwater aquaculture shares $80 \%$ of total inland fish production in India (DAHD, 2015-16).

The rapid expansions of the aquaculture industry, along with the improvement and change in culture techniques, have increased the demand for fish feeds. Feed cost is considered as the major recurring expenditure in any fish-culture operation. Expenditure on feed alone amounts to $60 \%$ of total fish production cost (Paul and Giri, 2015).

Commercial feeds for carp culture are available in the market but small fish farmers are unable to use these feeds because of their high cost. Traditional practice for fish farmers is to use mixture of groundnut oil cake and rice bran or cereals as fish feed. Recently the price of both the ingredients are highly increased which farmers are unable to afford (Rath et al., 2014) to feed the fish.

The Indian Council of Agricultural Research is operating an outreach program on "Fish feeds" among six fisheries research institutes, ICAR-CIFA, Bhubaneswar; ICAR-CIFRI, Barrackpore; ICAR-CIBA, Chennai; ICAR-CMFRI, Kochi; ICARDCFR, Bhimtal and ICAR-CIFE, Mumbai. The program has been undertaken to create awareness among the fish farmers across the country on the use of farm-made fish feeds to enhance production and popularization of fish culture in the rural sectors as well besides supporting their livelihood. Being the network leader ICAR-Central Institute of Freshwater Aquaculture under took several farmers awareness programs on fish feeds (Rath et al., 2014), hands-on training on farm feed preparation and feeding demonstration in farmers ponds in Odisha, West Bengal and Karnataka. Use of farm-made feed with locally available feed ingredients in rural aquaculture sectors open a new era for feed based aquaculture. Linseed oil is rich in omega-3 fatty acids and in the present experiment linseed oil sludge has been used as by-product of oil milling industry. The incorporation of linseed oil sludge in farm-made feed would improve the omega- 3 fatty acid profile of fish. Keeping in view of the above facts a 
feed demonstration program was undertaken at the ponds of Ramakrishna Mission, Belur Math with a view to use the locally available feed ingredients for production of fish enriched with omega-3 fatty acid.

\section{MATERIALS AND METHODS}

\section{Pond preparation}

Initially ponds were netted out repeatedly for two days with nylon dragnet followed by fry net to take out fish. Both the ponds are located in such places where chances of entry of predator and weed fishes are not there. Pond fertilization was carried out with application of cow dung and single super phosphate at 3 ton ha ${ }^{-1}$ and $75 \mathrm{~kg} \mathrm{ha}^{-1}$, respectively as a basal dose one week prior to stocking, with alternating applications every fortnight at 1 ton $\mathrm{ha}^{-1} \mathrm{month}^{-1}$ and $20 \mathrm{~kg} \mathrm{ha}^{-1} \mathrm{month}^{-1}$, respectively (Jena et al., 1999).

\section{Fish maintenance and feeding}

Under the Outreach Activity on Fish Feeds, two ponds were selected at Rama Krishna Mission, Belur Math, to provide hands-on training to 30 trainees at Samaj Sevak Sikshan Mandir (SSSM) on farm-made feed. Selected ponds were a) 0.1 ha at Shilpamandira (Feed-1) and b) 0.08 ha at SSSM (Feed-2) under the Sarada Pith unit of Belur Math. Both the ponds were stocked with rohu and catla juveniles at a stocking density of 4500 juveniles ha- ${ }^{1}$ and at a stocking ratio of catla:rohu was 90:10.. The stocking size of rohu was $80-90 \mathrm{~g}$ and for catla was 220-245 g. The objective of the program was to train the vocational trainees of RKM Samaj Sevak Sikshan Mandir through learning by doing mode, with a view to focus the utilization of locally available feed ingredients as cheap resources for fish feed making for low cost fish production.

Locally available low-cost feed ingredients were identified by surveying the local oil mills and procured. For the demonstration program two different farm-made feeds were formulated as per nutrient requirement guidelines of NRC (2011) for carps. Two mash feeds were prepared using rice bran, till oil cake, mustard oil cake and linseed sludge in different proportions for feeding the fish (Table 1). Linseed oil sludge is cheaply available in the oil milling industry as one of the by-product of crushing unit. Suitable feed dispensing mechanism were also developed, in which nylon bags were suspended on galvanized wire and connected by a small-pulley so that trainees can provide the feed regularly by standing on the pond side without going into the pond. Fish were fed at $2 \%$ of the body weight daily in two divided meals for a period of 8 months. Monthly sampling was done to assess the fish growth, health and calculate the ration requirement. Regular racking of pond water was practiced to release the obnoxious gases from the pond bottom due to accumulation of metabolites. 
Table 1. Feed formulations ( $\%$ as such basis)and proximate composition (\% DM basis)

\begin{tabular}{lccc}
\hline Ingredients & Feed-1 & Feed-2 \\
\hline Til oil cake & 60 & -- \\
Mustard oil cake & -- & 60 \\
Rice bran & 30 & 30 \\
Linseed oil sludge & 10 & 10 \\
& 100 & 100 \\
Proximate composition & & \\
Dry matter & 97.70 & 97.80 \\
Crude protein & 26.32 & 25.26 \\
Crude Fat & 4.61 & 5.20 \\
Ash & 17.78 & 18.02 \\
\hline
\end{tabular}

\section{Growth parameters}

Fishes were weighed at monthly intervals and mortality of fish was recorded. Net weight gain, feed conversion ratio (FCR), specific growth rate (SGR) and percent survival were calculated (Castell and Tiews, 1980).

\section{Proximate composition}

Proximate composition of feed and fish tissue samples was analyzed as per AOAC (2005). Water quality parameters such as $\mathrm{pH}$, DO, free $\mathrm{CO}_{2}$, total alkalinity and temperature were measured employing the method of APHA (2005).

\section{Fatty acid analysis}

Pooled samples were extracted for fatty acid analysis by following method of Folch et al. (1957). Fatty acid methyl esters (FAMEs) were prepared as per Metcalfe et al. (1966). The FAMEs were quantified by injected $1 \mu \mathrm{l}$ (50:1 split ratio) into (Gas Chromatograph/GC) Perkin Elmer; (CLARUS 480). Fatty acid was quantified through "Total Chrome" software in GC as reported earlier (Paul et al., 2015).

\section{RESULTS AND DISCUSSION}

Feed formulation and proximate composition of feed are presented in table 1 . The proximate compositions of the feeds are alike $(\mathrm{P}>0.05)$. The nutrient composition of linseed oil sludge is presented in table 2. The proximate compositions (\% DM basis) of linseed sludge was $4.4 \%$ crude protein, $19.00 \%$ fat and $40.83 \%$ ash. The saturated fatty acids (SFA) was determined as $9.42 \%$ of total fatty acids of the sludge and palmitic acid was the dominating SFA. The MUFA content was 16.83 and oleic acid was the leading fatty acid. The polyunsaturated fatty acid (PUFA) content was 73.76 $\%$ of the total fatty acids, where linolenic and linolelaidic acid were the dominant 
PUFAs. The water quality parameters are presented in table 3 . The water temperature ranged from $21-30^{\circ} \mathrm{C}$ in two ponds. The water quality parameters like $\mathrm{pH}, \mathrm{CO}_{2}$, total alkalinity $\left(\mathrm{mg} \mathrm{l}^{-1}\right)$ and dissolved oxygen $\left(\mathrm{mg} \mathrm{l}^{-1}\right)$ ranges from 7.4 to $7.8,4-8,130-160$ and 6.0-8.5 respectively in two different ponds, which is ideal for carp culture (Yadava and Garg, 1992; Hajek and Boyd, 1994, Azad et al. 2004; Swingle, 1969).

Table 2. Proximate composition (\% DM basis) and fatty acid composition (\% of total fatty acid) of Linseed sludge

\begin{tabular}{lll}
\hline Particulars & Linseed sludge \\
\hline Crude protein & 4.40 \\
Crude fat & 19.10 \\
Ash & 40.80 \\
Fatty acid composition & \\
C:16 Palmitic acid & 9.39 \\
Others & 0.03 \\
$\sum$ SFA & 9.42 \\
Oleic acid & 14.08 \\
Elaidic acid & 1.20 \\
Erucic acid & 1.45 \\
Others & 0.10 \\
$\sum$ MUFA & 16.83 \\
Linolelaidic acid & 16.83 \\
Linolenic acid & 46.05 \\
Others & 0.96 \\
$\sum$ PUFA & 73.76 \\
\hline
\end{tabular}

Table 3. Hydro biological parameters of ponds with different feed treatments

\begin{tabular}{ccc}
\hline Particulars & Feed-1 & Feed-2 \\
\hline Temperature & $21-29^{\circ} \mathrm{C}$ & $22-30{ }^{\circ} \mathrm{C}$ \\
$\mathrm{pH}$ & $7.5-7.8$ & $7.4-7.6$ \\
$\mathrm{CO}_{2}(\mathrm{ppm})$ & $6-8$ & $4-6$ \\
Total alkalinity $(\mathrm{ppm})$ & $150-160$ & $130-140$ \\
Dissolved oxygen $(\mathrm{ppm})$ & $6-8$ & $6-8.5$ \\
\hline
\end{tabular}

In the present demonstrated program the variations of total alkalinity were within the productive range for aquaculture ponds which also corroborate with the observations of Wahab et al. (1995) and Kohinoor et al. (1998). Good water quality is characterised by adequate oxygen levels in pond (Chiu (1988). Rahman et al. (1982) 
reported that dissolved oxygen content of a productive pond should be $5.0 \mathrm{mg}^{-1}$ or more.

The fish production performance of different ponds are presented in table 4 . The initial stocking size of rohu in two ponds ranged between 83.5 and $87.5 \mathrm{~g}$ while catla was 220.0 to $245.5 \mathrm{~g}$. The final average weight of catla and rohu was $1.61 \mathrm{~kg}$ and $1.07 \mathrm{~kg}$ respectively in the pond of Shilpamandira (Feed-1) whereas respective average weight of catla and rohu in the pond of SSSM (Feed-2) was recorded as 2.20 and $1.51 \mathrm{~kg}$ respectively. Survival rate of catla in the two ponds at the time of harvest was recorded to be 88 to $92 \%$ while rohu to be 93.3 to $93.91 \%$. The final fish biomass in the pond of Shilpamandira (Feed-1) was registered as $536.30 \mathrm{~kg}$ against $586.04 \mathrm{~kg}$ in the pond of SSSM (Feed-2), the net weight gain ( $\mathrm{kg}$ ) being $486.44 \mathrm{~kg}$ and $544.85 \mathrm{~kg}$ respectively. The feed conversion ratio (FCR) was 1.81 and while 1.61 in Feed-1 and 2 respectively. The demonstration resulted net production rate of 4.9

Table 4. Fish production in two ponds at Belur math fed on farm-made feeds

\begin{tabular}{lcc}
\hline Particulars & Feed-1 & Feed-2 \\
\hline Pond size (ha) & 0.10 & 0.08 \\
Fish stocked (4500 fish $\left.\mathrm{ha}^{-1}\right)$ & 450.00 & 360.00 \\
Initial av. wt.(g) of catla & 245.50 & 220.00 \\
Intial av wt.(g) of rohu & 83.50 & 87.50 \\
Survival at harvest (\%): catla & 92.00 & 88.00 \\
Survival at harvest (\%) : rohu & 93.30 & 93.910 \\
Final Av. wt.(kg): catla & 1.61 & 2.20 \\
Final Av. wt.(kg) :rohu & 1.07 & 1.51 \\
Total quantity at harvest $(\mathrm{kg}):$ & & \\
catla : & 74.06 & 96.80 \\
rohu : & 462.24 & 489.24 \\
Net biomass gain $\left(\mathrm{kg}^{\prime}\right)$ & 486.44 & 544.85 \\
Total feed intake $\left(\mathrm{kg} 8\right.$ month $\left.^{-1}\right)$ & 880.00 & 878.00 \\
FCR & 1.80 & 1.60 \\
SGR $(\%)$ & 1.01 & 1.13 \\
Net production $\left(\mathrm{t} \mathrm{ha}^{-1} 8\right.$ month $\left.^{-1}\right)$ & 4.90 & 6.80 \\
Feed cost (Rs.) $\mathrm{kg}^{-1}$ & 15.70 & 18.70 \\
Feed cost (Rs.) $\mathrm{kg}^{-1}$ fish production & 28.26 & 29.92 \\
\hline
\end{tabular}

Av. wt $=$ Average weight 
and $6.8 \mathrm{t} \mathrm{ha}^{-1} 8$ months $^{-1}$ respectively in Feed-1 and 2. At the end of the demonstration the trainees of RKMSSSM developed skill with self confidence to adopt aquaculture practice as one of the avenues to upgrade their livelihood status and scope for selfreliance as well.

Table 5 represents the proximate composition (\%w/w basis) of rohu and catla of initial and final samples of both the ponds. The moisture content varies from 69.92 to $74.18 \%$. The protein content varies from 14.13 to $17.70 \%$, fat from 2.92 to $4.43 \%$ and ash content from 2.62 to $6.05 \%$ in catla and rohu of different ponds fed with farm-made feed. The fish carcass composition was higher in both rohu and catla after 8 months of experimental period. The data reported in this experiment is in agreement with the earlier report by Paul et al. (2016)

Table 5. Carcass composition (\% w/w basis) of rohu and catla fed with farm-made feed

\begin{tabular}{c|c|c|c|c|c|c}
\hline \multirow{2}{*}{ Particulars } & \multicolumn{2}{|c|}{ Initial sample } & \multicolumn{2}{c|}{ Feed-1 } & \multicolumn{2}{c}{ Feed-2 } \\
\cline { 2 - 7 } & Rohu & Catla & Rohu & Catla & Rohu & Catla \\
\hline Moisture & $78.65 \pm 0.96$ & $74.44 \pm 0.38$ & $74.13 \pm 0.94$ & $74.18 \pm 0.67$ & $75.29 \pm 0.22$ & $69.92 \pm 1.11$ \\
Protein & $12.69 \pm 0.30$ & $12.60 \pm 0.29$ & $14.13 \pm 0.33$ & $14.64 \pm 0.04$ & $14.57 \pm 0.14$ & $17.70 \pm 0.06$ \\
Fat & $1.77 \pm 0.28$ & $2.27 \pm 0.06$ & $3.25 \pm 0.04$ & $3.85 \pm 0.01$ & $2.92 \pm 0.07$ & $4.43 \pm 0.08$ \\
Ash & $2.12 \pm 0.04$ & $2.41 \pm 0.05$ & $3.42 \pm 0.07$ & $2.62 \pm 0.06$ & $3.82 \pm 0.0005$ & $6.05 \pm 0.09$ \\
\hline
\end{tabular}

Data are presented as Mean \pm S.E

The fatty acid profile of rohu and catla of initial and final samples of two ponds are presented in table 6 . The saturated fatty (SFA) acid content of carcass of rohu at the beginning of the demonstration was $65.88 \%$, which decreased to $53.57 \%$ and 52.23 $\%$ of the total fatty acids, at the end of demonstration, on feeding Feed-1 and Feed-2, respectively. Similarly, in catla the carcass SFA at the beginning was $33.87 \%$ and increased to $61.54 \%$ and $40.72 \%$ with Feed-1 and 2, respectively in the final harvest samples. The predominate fatty acid among SFA was palmitic acid. The palmitic acid was considered as a key to many metabolic processes in fish and other aquatic animals as reported by Ackman and Eaton (1966). In the muscle of rohu, palmitic acid is higher which is in agreement with the earlier report by Paul et al. (2013).

The monounsaturated fatty acid content ranges from 23.67 to $38.76 \%$ in initial carcass sample of catla as well as rohu. However, the MUFA content in harvested sample of rohu and catla were 24.80 to 26.40 and 12.54 to $36.53 \%$, respectively and the dominating fatty acid of MUFA class is Oleic acid. The polyunsaturated fatty acid (PUFA) content in initial samples were 10.47 to $27.36 \%$ in rohu and catla. The 
Table 6. Fatty acid profile of (\% of total fatty acid) of rohu and catla

\begin{tabular}{|c|c|c|c|c|c|c|}
\hline \multirow[t]{2}{*}{ Fatty Acid } & \multicolumn{2}{|c|}{ Initial Sample } & \multicolumn{2}{|c|}{ Feed-1 } & \multirow{2}{*}{$\begin{array}{c}\text { Feed-2 } \\
\text { rohu }\end{array}$} & \multirow[b]{2}{*}{ catla } \\
\hline & rohu & catla & rohu & catla & & \\
\hline Lauric Acid & - & 0.22 & 0.05 & 0.23 & 10.23 & 0.11 \\
\hline Myristic Acid & 3.67 & 5.12 & 1.10 & 6.16 & 2.92 & 1.89 \\
\hline Pentadeconoic Acid & 1.94 & 1.51 & 0.24 & 3.34 & 2.50 & 0.92 \\
\hline Palmitic Acid & 46.87 & 19.80 & 46.08 & 31.51 & 25.60 & 23.63 \\
\hline Heptadeconoic Acid & 2.44 & 2.59 & 0.22 & 1.11 & 4.27 & 0.90 \\
\hline Stearic Acid & 8.16 & 0.01 & 4.68 & 14.27 & 0.05 & 10.96 \\
\hline Heneicosanoic Acid & & 1.81 & 0.36 & 2.15 & 4.25 & 1.33 \\
\hline Tricosanoic Acid & & 1.49 & 0.64 & 0.31 & 1.57 & 0.14 \\
\hline Others & 2.80 & 1.32 & 0.02 & 2.46 & 0.84 & 0.90 \\
\hline$\sum \mathrm{SFA}$ & 65.88 & 33.87 & 53.57 & 61.54 & 52.23 & 40.72 \\
\hline Palmitoleic Acid & 6.21 & 0.91 & 0.98 & 9.89 & 7.52 & 4.12 \\
\hline Oleic Acid & 15.01 & 22.67 & 22.75 & - & - & 30.4 \\
\hline Eladic Acid & - & 11.03 & - & - & 17.89 & - \\
\hline Eicosanoic Acid & - & 2.16 & - & - & - & - \\
\hline Erucic Acid & 0.57 & 0.09 & 0.78 & 1.01 & 0.21 & 0.91 \\
\hline Others & 1.89 & 1.90 & 0.29 & 1.64 & 0.78 & 1.10 \\
\hline$\sum$ MUFA & 23.67 & 38.76 & 24.80 & 12.54 & 26.40 & 36.53 \\
\hline Linoleic Acid & 4.66 & 7.56 & 12.86 & 7.97 & 9.87 & 13.73 \\
\hline Linolenic Acid & 2.70 & 14.19 & 6.91 & 7.09 & 4.71 & 4.12 \\
\hline Arachidonic Acid & 0.37 & 1.06 & 0.02 & 0.64 & 0.76 & 0.92 \\
\hline EPA & 1.36 & 3.95 & 0.06 & 2.35 & 0.99 & 0.85 \\
\hline DHA & 0.70 & - & 0.89 & 3.54 & 3.09 & 2.15 \\
\hline Others & 0.68 & 0.60 & 0.91 & 1.27 & 1.96 & 0.97 \\
\hline$\sum$ PUFA & 10.47 & 27.36 & 21.65 & 22.86 & 21.38 & 22.74 \\
\hline$\sum \omega 3$ & 4.83 & 17.72 & 7.96 & 12.82 & 9.36 & 6.30 \\
\hline$\sum \omega 6$ & 5.64 & 9.64 & 13.42 & 10.04 & 11.57 & 15.59 \\
\hline$\omega 3: \omega 6$ & 0.85 & 1.84 & 0.59 & 1.28 & 0.80 & 0.40 \\
\hline
\end{tabular}

SFA- Saturated Fatty Acid, MUFA- Monounsaturated Fatty Acid, PUFA-Polyunsaturated Fatty Acid, EPA-Eicosapentaenoic Acid and DHA-Docosahexaenoic Acid.

PUFA content in both the species of the two treatment groups range from 21.38 to $22.86 \%$. Here the predominant fatty acids are linolenic, linoleic, eicosapentaenoic acid (EPA) and docosahexaenoic acid (DHA). The EPA content of initial samples was 1.36 to $3.95(\%)$. The EPA content of rohu from both the feed treatment groups ranges from 0.06 to $0.99 \%$ while DHA content in the same species varies from 0.89 
to $3.09(\%)$ in Feed-1 and 2. Value of EPA content in harvested catla of both ponds ranges from 0.85 to $2.35 \%$ and DHA content of 2.15 to $3.54 \%$. Steffens and Wirth (2005) reported that freshwater fish are rich in essential polyunsaturated fatty acid of the n-3and n-6 series, which is in agreement with fillet composition of experimental catla and rohu. Compared to beef and chicken, fish meat contains higher levels of n-3 PUFAs Calder (2004), which are known to be cardio-protective (Sanderson et al., 2002) and antithrombotic (Calder, 2004). Fish oils are known to be rich source of essential PUFA of the omega-3 family (Kenari et al., 2009 and Giri et al., 2010). The data on fatty acid profile of catla and rohu as reported in the paper are in agreement with earlier reports (Memon et al., 2011 and Paul et al., 2015). This indicates that the fish reared with farm-made omega-3 feed tailored the fatty acid profile of harvested fish tissue. The feed cost was substantially reduced by replacing mustard oil cake with til oil cake and with incorporation of linseed oil sludge, a very low priced ingredient.

\section{ACKNOWLEDGEMENT}

This work is supported by Ministry of Agriculture, Govt. of India under outreach activity on "Fish Feeds". The authors express sincere gratitude to Deputy Director General (Fy.) ICAR and Director ICAR-CIFA for providing necessary facility and taking keen interest to conduct the work. The authors also like to record their deep sense of gratitude with ingenuous regards to Revered Swami Divyananda, Secretary and Swami Shastrarupananda of Saradapitha and Revered Swami Sivakarananda, Principal, Samaj Sevak Sikshan Mandir, Ramakrishna Mission, Belur math for providing infrastructure facilities for the demonstration study at Belur Math, Howrah.

\section{REFERENCES}

AOAC. (1995). Official methods of Analysis, $18^{\text {th }}$ ed. Association of Official Analytical Chemists, Washinton, D.C.

APHA. (2005). Standard methods for examination of water and wastewater, $21^{\text {st }}$ ed. American Public Health Association, Washington, D.C.

Ackman, R.G., and Eaton, C.A. 1966. Some commercial Atlantic herring oils; Fatty acid composition. Journal of Fisheries Research Board of Canada, 23, 991-1006.

Azad, M.A.K., Rahman, M.R.Z., Rahman, M.A., Kader, Haque, M.M., and Alam, M.J. 2004. Polyculture of carps, tilapia and pangus using low cost inputs. Pakistan Journal Biological Science, 7(11), 1918-1926.

Castell, J.D., and Tiews, K. (1980). Report of the EIFAC, IUNS and ICES working group on Standardization of Methodology in Fish Nutrition Research. EIFAC/T36, EIFA/FAO. p. 24.

Calder, P.C. 2004. Long-chain fatty acids and cardiovascular disease: further evidence and insights. Nutrition Research, 24, 761-772. Doi: 10.1016/j.nutres.2004.04.008. 
B.N. Paul et al.

Chiu, Y.N. (1988). Water quality management for intensive prawn ponds. In: Y.N. hi, L.M.

Santos and R.O. Juliano (eds), Technical Considerations for the Management and Operation of Intensive Prawn Farm. Aquaculture Society, Philippines, p. 102-129.

DAHAD. (2015). Annual Report, 2014-15. Department of Animal Husbandry and Fisheries, Government of India, p.7.

FAO. 2010. FAOSTAT. Food and Agricultural Organization of the United Nations, Rome, Italy.

Folch, J., Less, M., and Stanley, G.H.S. (1957).A simple method for the isolation and purification of total lipids from animal tissues. Journal of Biochemistry, 226, 497-509.

Giri, S.S., Paul, B.N., Sahoo, S.K., Rangacharyulu, P.V., Rath, S.C., and Mohanty, S.N. (2010). Fish oils and cardio vascular health. Fishing Chimes, 30, 37-39.

Hajek, B.F., and Boyd, C.E. (1994). Rating soil and water information for aquaculture. Aquaculture Engineering, 13, 115-128.

Jena, J.K., Mukhopadhyay, P.K., and Aravindakshan, P.K. (1999).Evaluation of a formulated diet for raising carp fingerlings in field conditions. Journal of Applied Icthyology, 15, 188-192.

Kenari, A.A., Regenstein, J.M., Rezai, M., Tahergorabi, R., Nazari, R.M., Mogaddasi, M., and Kaboli, S.A. (2009). Amino acid and fatty acid composition of cultured Beluga (Huso huso) of different ages. Journal of Aquatic Food Product and Technology, 18, 245-265.

Kohinoor, A.H.M., Islam, M.L., Wahab, M.A., and Thilsted, S.H. (1998). Effect of mola (Amblypharyngodon mola Ham.) on the growth and production of carps in polyculture. Bangladesh Journal of Fisheries, 2(2), 111-126.

Memon, N.N., Farah, N.L., Bhanger, M.I., and Balouch, A. (2011). Changes in aftty acid composition in muscle of three farmed carp species (Labeo rohita, Corrhinus mrigala, Catla catla) raised under the same conditions. Food Chemistry, 126, 405-410.

Metcalfe, L.D., Schmitz, A.A., and Petha, J.R. (1966). Rapid preparation of fatty acid esters from lipids for gas chromatographic analysis. Anaytical Chemists, 38, 514-515.

NRC. (2011). Nutrient requirement of Fish and Shrimp. National Academy Press, Washington D.C.

Paul, B.N., and Giri, S.S. (2015). Freshwater Aquaculture Nutrition Research in India. Indian Journal of Animal Nutrition, 32 (2), 113-125.

Paul, B.N., Chanda, S., Sridhar, N., Saha, G.S., and Giri, S.S. (2015). Fatty acid profile of Indian Major Carp. Indian Journal of Animal Nutrition, 32(2), 221-226.

Paul, B.N., Chanda, S., Sridhar, N., Saha, G.S., and Giri, S.S. (2016). Proximate, mineral and vitamin contents of Indian Major Carp. Indian Journal of Animal Nutrition, 33(1), 102107. Doi: 10.5958/2231-6744.2016.00018.9.

Rahman, M.S., Chowdhury, M.Y., Haque, A.K.M.A., and Haq, M.S.(1982). Limnological studies of four ponds. Bangladesh Journal of Fisheries, 2-5(1-2), 25-35.

Rath, S.C., Nayak, K.C., Mahanta, K.N., Giri, S.S., Mohanty, S.N. (2014). Carp polyculture by farm feed intervention in farmers pond in Odisha. Indian Farming, 64(7), 51-55. 
Sanderson, P., Finnegan, Y.E., Williams, C.M., Calder, P.C., Burdge, G.C., Wootton, S.A., Griffin, B.A., Millward, D.J., Pegge, N.C., and Bemelmans, W.J.E. (2002). UK food standards agency alpha-linolenic acid workshop report. British Journal of Nutrition, 88, 573-579, doi: 10.1079/BJN2002691.

Steffens, W., and Wirth, M. (2005). Freshwater fish- an important source of N-3 Polyunsaturated fatty acids: A review. Archives of Polish Fisheries, 13(1), 5-16.

Swingle, H.S. (1969). Standardization of chemical analysis for waters and pond mud. FAO. Fisheries Research, 4(2), 397-421.

Wahab, M.A., Ahmed, Z.F., Haque, M.S., Haque, M.A. and Biswas, B.K. (1995). Effect of frequency of fertilization on the pond ecology and growth of fishes. BAU Research Progress, 9, 410-419.

Yadav, N.K., and Garg, S.K. (1992). Relative efficiency of different doses of organic fertilizer and supplement feed utilization under intensive fish farming. Bioresource Technology, $42,61-5$. 